\title{
The leishmanicidal activity of essential oils: A systematic review
}

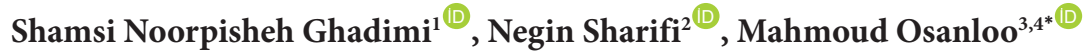 \\ ${ }^{1}$ Department of Parasitology and Mycology, School of Medicine, Fasa University of Medical Sciences, Fasa, Iran \\ ${ }^{2}$ Department of Medicine, School of Medicine, Fasa University of Medical Sciences, Fasa, Iran \\ ${ }^{3}$ Department of Medical Nanotechnology, School of Advanced Technologies in Medicine, Fasa, Iran \\ ${ }^{4}$ Noncommunicable Diseases Research Center, Fasa University of Medical Sciences, Fasa, Iran
}

\section{AR T I C L E I N F O}

Article Type:

Review

\section{Article History:}

Received: 14 November 2019

Accepted: 10 February 2020

\section{Keywords:}

Systematic review

Essential oil

Leishmania

Promastigotes

Leishmanicidal activity

\begin{abstract}
A B S T R A C T
Leishmaniasis is the neglected disease among parasitic diseases with an increasing rate of infections. Recently, numerous studies have been conducted on the leishmanicidal properties of various essential oils (EOs). In this research, literature have been systematically reviewed, from 20 years ago, and required information have been extracted. Overally, leishmanicidal effects of 180 EOs against promastigotes of nine species of Leishmania have been documented. Inhibitory concentrations 50\% (IC50) of around 30 EOs were less than 10 $\mu \mathrm{g} . \mathrm{mL}^{-1}$. EOs of Tetradenia riparia, Nectandra hihua, and Thymus hirtus with IC50s of 0.01, 0.20 , and $0.25 \mu \mathrm{g} \cdot \mathrm{mL}^{-1}$ against Leishmania amazonensis, Leishmania infantum, and Leishmania major respectively, were identified as the most effective EOs. Furthermore, IC50 of Thymus hirtus on Leishmania infantum was $0.43 \mu \mathrm{g} \cdot \mathrm{mL}^{-1}$. Frequently, substantial differences were found between the observed IC50s of one EO against promastigotes of different species of Leishmania. It can be concluded that the leishmanicidal activity of EOs is selective. Turning to the results, the combination of EOs for the design of multifunctional drugs can lead to excellent outcomes. Interestingly, the results have been classified by promastigote species, so this would be a valuable benchmark for researchers.
\end{abstract}

Implication for health policy/practice/research/medical education:

This review provided a detailed insight into the leishmanicidal activities of around 180 plant-derived essential oil and showed that some of them could be used as a reliable source for developing new drugs or nano/formulations.

Please cite this paper as: Noorpisheh Ghadimi S, Sharifi N, Osanloo M. The leishmanicidal activity of essential oils: A systematic review. J Herbmed Pharmacol. 2020;9(4):300-308. doi: 10.34172/jhp.2020.38.

\section{Introduction}

Leishmaniasis is one of the most important vectortransmitted diseases which has the second rank after malaria in terms of mortality caused by a parasite disease (1). Leishmaniasis is currently endemic in 102 countries. Countries such as Iran, Afghanistan, Syria, Algeria, North Sudan, Ethiopia, Peru, Colombia, Costa Rica, and Brazil have the highest incidence of leishmaniasis $(2,3)$. An estimated 700000 to 1 million new cases, and 26000 to 65000 deaths occur, annually (4).

Leishmaniasis is caused by an obligate intracellular parasite of the genus Leishmania (Trypanosomatida) (5) and transmitted by the bite of infected females of sand flies (Family: Phlebotominae) (6). This disease can be seen in various forms, including cutaneous, visceral, and mucosal leishmaniasis (7). Leishmania parasites have two forms in their life cycle, including amastigote and promastigote (8).

Considering the growing number of new cases, the development of new drugs is critical. Plant-derived essential oils (EOs) are natural oil that secreted as secondary metabolites from different parts of the aromatic plants (9). EOs composed of a mixture of hydrophilic and hydrophobic molecules (10). They possess various biological activities such as larvicidal effect (11), antibacterial properties (12), and antifungal aspect (13), and introduces an excellent source for finding new drugs (14).

Recently leishmanicidal activities (LCA) of EOs have received much attention. Moreover, their effects on promastigotes of different species of Leishmania have been 
reported frequently $(15,16)$. In this research, the LCA of EOs on different types of promastigotes systematically have been reviewed, form January 1, 2000 to June 30, 2019.

\section{Data collection}

Due to much publication on investigating LCA of EOs, data collection was included just to PubMed website (https://www.ncbi.nlm.nih.gov/pubmed/advanced). Steps for finding proper reports were described as follow:

A: Included dates: 2000.01.01 - 2019.06.30.

B: Leishmania*[Title/Abstract]

C: Essential oil*[Title/Abstract]

D: Leishmania*[Title/Abstract]) AND essential oil*[Title/ Abstract]: 120 docs.

Full texts of all 120 papers were collected. Required information including scientific names of plants, parts of used for EOs extraction, and inhibitory concentration $50 \%$ (IC50) were also extracted. Fifty-five articles that had no reported IC50 were excluded. It should be noted that IC50 is a quantitative measure that indicates how much of an EO is needed to inhibit $50 \%$ of promastigotes growth in comparison to control groups, no treated with EO.

\section{Leishmanicidal activity of essential oils}

LCA of 179 EOs on promastigotes of 9 species of Leishmania was extracted from 66 documents. Those species were L. amazonensis (71 reports), L. braziliensis (15 reports), L. chagasi (14 reports), L. donovani (8 reports), $L$. infantum (17 reports), L. major (31 reports), L. mexicana
(9 reports), L. panamensis (9 reports), and L. tropica (5 reports). Collected information about each species was listed in tables of 1-9 as follows:

LCA of EOs on promastigotes of L. amazonensis was listed in Table 1. L. amazonensis is an etiological agent of human cutaneous leishmaniasis in the Amazon region of Brazil from New World (17). The most potent EO was Tetradenia riparia with IC50 of $<1 \mu \mathrm{g} \cdot \mathrm{mL}^{-1}(18-20)$. Interestingly, LCA of 15 other EOs including Cymbopogon citratus, Eugenia uniflora, Nectandra gardneri, Protium ovatum, Chenopodium ambrosioides, Eugenia uniflora, Chenopodium ambrosioides, Chenopodium ambrosioide (Wild Type), Cryptocarya aschersoniana, Ocotea dispersa, Chenopodium ambrosioide, Nectandra megapotamica, Chenopodium ambrosioide, Anillosmopsis arborea, and Achillea millefolium were lower than $10 \mu \mathrm{g} \cdot \mathrm{mL}^{-1}$. These mentioned EOs are excellent candidates for the development of new drugs.

Table 2 contains a list of EOs with their IC50s on promastigotes of $L$. braziliensis; in the new world is causative agents of cutaneous leishmaniasis (51). Among the examined EOs, IC50 ( $\left.\mu \mathrm{g} \cdot \mathrm{mL}^{-1}\right)$ of 3 EOs were lower than others; Lantana camara: 72.30 (52), Piper aduncum: 77.90 (53), and Piper auritum: 52.10 (54).

The most common form of leishmaniasis is cutaneous leishmaniasis, which causes several types of skin lesions on exposed parts of the body such as ulcers, leaving lifelong scars and severe disability or stigma $(55,56)$.

Table 3 reports the LCA of many EOs against L. chagasi.

Table 1. Leishmanicidal activities of EOs on promastigotes of Leishmania amazonensis

\begin{tabular}{|c|c|c|c|}
\hline Plant name & Part(s) of use & IC50 ( $\left.\mu \mathrm{g} \cdot \mathrm{mL}^{-1}\right)$ & References \\
\hline Achillea millefolium & Leaves/ flowers & 7.80 & $(21)$ \\
\hline Aloysia gratissima & Aerial part & 25.00 & $(22)$ \\
\hline Artemisia absinthium & Leaves & 21.50 & (23) \\
\hline Artemisia absinthium & Leaves & 14.40 & (24) \\
\hline Bulnesia sarmientoi & Leaves/ stems & 85.50 & $(25)$ \\
\hline Cananga odorata & Leaves/ stems & NSV* & (25) \\
\hline Chenopodium ambrosioides & Green leaves & 2.90 & (26) \\
\hline Chenopodium ambrosioides & Dry leaves & 20.70 & (26) \\
\hline Chenopodium ambrosioide (After IP treatment) & Aerial parts & 6.71 & (27) \\
\hline Chenopodium ambrosioide (After $\mathrm{O}$ treatment) & Aerial parts & 5.55 & (27) \\
\hline Chenopodium ambrosioide (wild type) & Aerial parts & 3.74 & $(27)$ \\
\hline Chenopodium ambrosioides & $\mathrm{N} / \mathrm{A}$ & 3.70 & (28) \\
\hline Cinnamodendron dinisii & Leaves/ stems & 54.00 & $(25)$ \\
\hline Cinnamomum camphora & Leaves/ stems & NSV & $(25)$ \\
\hline Cinnamomum zeylanicum & Leaves & NSV & (29) \\
\hline Cordia verbenaceae & Leaves/ stems & 64.70 & $(25)$ \\
\hline Coriandrum sativum & Seeds & 19.10 & (30) \\
\hline Cryptocarya aschersoniana & Leaves & 4.46 & (31) \\
\hline Curcuma longa & Aerial parts & 405.50 & (29) \\
\hline Cymbopogon citratus & Leaves & 1.70 & (32) \\
\hline Elettaria cardamomum & Leaves/ stems & NSV & $(25)$ \\
\hline
\end{tabular}


Table 1. Continued

\begin{tabular}{|c|c|c|c|}
\hline Plant name & Part(s) of use & IC50 ( $\mu \mathrm{g} . \mathrm{mL}^{-1}$ ) & References \\
\hline Eugenia uniflora & Leaves & 3.04 & (33) \\
\hline Eugenia uniflora & Leaves & 1.75 & (33) \\
\hline Ferula galbaniflua & Leaves/ stems & 95.70 & $(25)$ \\
\hline Foeniculum officinalis & Leaves/ stems & 328.20 & (25) \\
\hline Gualtheria fragrantissima & Leaves & 22.20 & (30) \\
\hline Lavandula officinalis & Leaves/ stems & NSV & (25) \\
\hline Lippia sidoides & Aerial parts & 44.38 & (34) \\
\hline Litsea cubeba & Leaves/ stems & NSV & (25) \\
\hline Matricaria chamomilla & Leaves/ stems & 60.10 & $(25)$ \\
\hline Melissa officinalis & Leaves/ stems & 132.00 & (25) \\
\hline Myracrodruon urundeuva & Leaves & 205.00 & (35) \\
\hline Myroxylon peruiferum & Leaves/ stems & 162.20 & $(25)$ \\
\hline Nectandra amazonum & Leaves & 22.10 & (36) \\
\hline Nectandra gardneri & Leaves & 2.10 & (36) \\
\hline Nectandra megapotamica & Leaves & 6.66 & (37) \\
\hline Nectandra megapotamica & Leaves & 21.30 & (36) \\
\hline Ocimum gratissimum & Leaves & 135.00 & (38) \\
\hline Ocotea dispersa & Leaves & 4.67 & (39) \\
\hline Ocotea odorifera & Leaves & 11.67 & (39) \\
\hline Origanum vulgare & Aerial parts & 308.40 & (29) \\
\hline Pelargonium graveolens & Leaves/ stems & 363.70 & (25) \\
\hline Piper aduncum & Leaves & 19.30 & (40) \\
\hline Piper aduncum. & Leaves & 25.90 & (41) \\
\hline Piper arboretum & Leaves & 15.20 & (41) \\
\hline Piper cernuum & Leaves & 27.10 & $(41)$ \\
\hline Piper claussenianum & Leaves & 30.40 & $(42)$ \\
\hline Piper claussenianum & Inflorescence & NSV & $(42)$ \\
\hline Piper cubeba & Fruits & 326.50 & (43) \\
\hline Piper demeraranum & Leaves & 86.00 & (44) \\
\hline Piper diospyrifolium & Leaves & 13.50 & (41) \\
\hline Piper duckei & Leaves & 46.00 & (44) \\
\hline Piper gaudichaudianum & Leaves & 93.50 & (41) \\
\hline Piper mikanianum & Leaves & NSV & (41) \\
\hline Piper mosenii & Leaves & 17.40 & (41) \\
\hline Piper ossanum & Leaves & NSV & (40) \\
\hline Piper rivinoides & Leaves & 10.90 & (41) \\
\hline Piper xylosteoides & Leaves & NSV & (41) \\
\hline Pluchea carolinensis & Leaves & 24.70 & $(45)$ \\
\hline Protium ovatum & Leaves & 2.280 & (46) \\
\hline Salvia sclarea & Leaves/ stems & 325.90 & (25) \\
\hline Siparuna guianensis & Leaves/ stems & 48.50 & $(25)$ \\
\hline Syzygium cumini & Leaves & 36.00 & (47) \\
\hline Syzygium cumini & Leaves & 60.00 & (47) \\
\hline Syzygium cumini & Leaves & 115.00 & (47) \\
\hline Syzygium cumini & Steam & 19.70 & (48) \\
\hline Tetradenia riparia & Leaves & 0.53 & (20) \\
\hline Tetradenia riparia & Leaves & 0.03 & (19) \\
\hline Tetradenia riparia & Leaves & 0.01 & (18) \\
\hline Tunisian chamomile & Flower & 10.80 & (49) \\
\hline Vanillosmopsis arborea & Stems & 7.35 & (50) \\
\hline
\end{tabular}

*No specified value; IC50 >X. 
Table 2. Leishmanicidal activities of EOs against promastigotes of Leishmania braziliensis

\begin{tabular}{lccc}
\hline Plant name & Part(s) of use & IC50 $\left(\mu \mathrm{g} \cdot \mathrm{mL}^{-1}\right)$ & References \\
\hline Argyreia speciosa & Leaves & 104.14 & $(57)$ \\
Citrus limon & Leaves & NSV* & $(58)$ \\
Citrus sinensis & Leaves & NSV & $(58)$ \\
Coriandrum sativum & Leaves & NSV & $(58)$ \\
Cymbopogon citratus & Leaves & 194.05 & $(58)$ \\
Lantana camara & Leaves & 72.30 & $(52)$ \\
Mentha piperita & Leaves & NSV & $(58)$ \\
Ocimum basilicum & Leaves & NSV & $(58)$ \\
Origanum vulgare & Leaves & 171.80 & $(58)$ \\
Piper aduncum & Leaves & 77.90 & $(53)$ \\
Piper auritum & Leaves & 52.10 & $(54)$ \\
Piper tuberculatum & Fruits & 133.97 & $(59)$ \\
Rosmarinus officinalis & Leaves & $\mathrm{NSV}$ & $(58)$ \\
Thymus vulgaris & Leaves & $\mathrm{NSV}$ & $(58)$ \\
Zingiber officinale & Leaves & 303.00 & $(58)$ \\
\hline No specified value; & X. & &
\end{tabular}

*No specified value; IC50 > X.

Table 3. Leishmanicidal activities of EOs against promastigotes of Leishmania chagasi

\begin{tabular}{lccc}
\hline Plant name & Part(s) of use & IC50 ( $\mu \mathrm{g} \cdot \mathrm{mL}^{-1}$ ) & References \\
\hline Copaifera reticulata & Seeds & 7.88 & $(62)$ \\
Coriandrum sativum & Seeds & 181.00 & $(62)$ \\
Croton cajucara & Leaves & 66.70 & $(63)$ \\
Cymbopogon citratus & Leaves & 45.00 & $(64)$ \\
Lippia alba & Aerial parts & 18.90 & $(65)$ \\
Lippia citriodora & Aerial parts & 5.20 & $(65)$ \\
Lippia dulcis & Aerial parts & 37.10 & $(65)$ \\
Lippia gracilis (LGRA-106) & Leaves & 86.32 & $(66)$ \\
Lippia gracilis (LGRA-110) & Leaves & 77.26 & $(66)$ \\
Lippia idoides & Leaves & 89.00 & $(64)$ \\
Lippia micromera & Aerial parts & 51.80 & $(65)$ \\
Lippia origanoides & Aerial parts & 4.40 & $(65)$ \\
Lippia sidoides & Seeds & 19.76 & $(62)$ \\
Ocimum gratissimum & Leaves & 75.00 & $(64)$ \\
\hline
\end{tabular}

In the new world, visceral leishmaniasis is associated with L. Chagasi (60). As details show, IC50 of 3 EOs, including Copaifera reticulate, Lippia citriodora, and Lippia origanoides, are around $5 \mu \mathrm{g} \cdot \mathrm{mL}^{-1}$. These EOs are suitable candidates for in-vivo studies.

A fatal form of leishmaniasis is visceral, in which parasite affects internal organs such as the spleen, liver, and bone marrow (61).

Table 4 shows the leishmanicidal potency of eight EOs on L. donovani. In India and West Africa, L. donovani is
Table 4. Leishmanicidal activities of EOs against promastigotes of Leishmania donovani

\begin{tabular}{lccc}
\hline Plant name & Part(s) of use & IC50 $\left(\boldsymbol{\mu g} \cdot \mathrm{mL}^{-1}\right)$ & References \\
\hline Artemisia annua & Leaves & 14.60 & $(68)$ \\
Baccharis dracunculifolia & Leaves & 42.00 & $(70)$ \\
Mentha piperita & N/A & 50.00 & $(71)$ \\
Ocimum basilicum Mesten & Steam & 49.60 & $(72)$ \\
Ocimum basilicum German & Steam & 48.30 & $(72)$ \\
Ocimum sanctum & Steam & 37.30 & $(72)$ \\
Piper auritum & Leaves & 12.80 & $(54)$ \\
Syzygium aromaticum & Flower buds & 21.00 & $(69)$ \\
\hline
\end{tabular}

the causative agent of visceral leishmaniasis (Kala-azar) (67). Among the reported IC50s, EOs of Artemisia annua, Piper auritum, and Syzygium aromaticum with values of $14.60,12.80$, and $21.00 \mu \mathrm{g} \cdot \mathrm{mL}^{-1}$ respectively, were more effective than others $(54,68,69)$.

In Table 5, IC50 of some EOs on L. infantum are summarized. L. infantum infection (causes of visceral leishmaniasis) is endemic in Southern Europe (73). LCA of Nectandra hihua and Thymus hirtus EOs with IC50 of 0.20 and $0.25 \mu \mathrm{g} \cdot \mathrm{mL}^{-1}$ were very phantasies $(36,74)$.

Results of LCA of some medicinal plants on L. major are summarized in Table 6. L. major and L. tropica in the old world are responsible for cutaneous leishmaniasis (7). Interestingly 3 documented IC50s were around $1 \mu \mathrm{g} \cdot \mathrm{mL}^{-1}$; those values were related to EOs of Mentha pulegium, Rosmarinus officinalis, and Thymus hirtus.

Table 7 summarizes the effect of many EOs on $L$. mexicana, which is one of the primary causes of cutaneous

Table 5. Leishmanicidal activities of EOs against promastigotes of Leishmani infantum

\begin{tabular}{lccc}
\hline Plant name & Part(s) of use & $\begin{array}{c}\text { IC50 } \\
\left(\mu \mathrm{g} \cdot \mathrm{mL}^{-1} \text { ) }\right.\end{array}$ & References \\
\hline Artemisia campestris & Leaves/ stems & 44.00 & $(75)$ \\
Artemisia herba-alba & Leaves/ stems & 68.00 & $(75)$ \\
Cymbopogon citratus & Aerial parts & 25.00 & $(76)$ \\
Guatteria australis & Leaves & 30.71 & $(77)$ \\
Nectandra amazonum & Leaves & 31.90 & $(36)$ \\
Nectandra gardneri & Leaves & 2.70 & $(36)$ \\
Nectandra hihua & Leaves & 0.20 & $(36)$ \\
Nectandra megapotamica & Leaves & 12.50 & $(36)$ \\
Nigella sativa & Seeds & 11.70 & $(78)$ \\
Piper aduncum & Leaves & 32.50 & $(40)$ \\
Piper ossanum & Leaves & 32.50 & $(40)$ \\
Piper tuberculatum & Fruits & 143.59 & $(59)$ \\
Pulicaria vulgaris & Aerial parts & 233.60 & $(79)$ \\
Thymus capitellatus & Aerial parts & 37.00 & $(80)$ \\
Thymus hirtus & N/A & 0.25 & $(74)$ \\
Tunisian chamomile & Flower & 10.40 & $(49)$ \\
Vernonia polyanthes & Leaves & 19.40 & $(81)$ \\
\hline
\end{tabular}


Table 6. Leishmanicidal activities of EOs against promastigotes of Leishmania major

\begin{tabular}{|c|c|c|c|}
\hline Plant name & Part(s) of use & $\mathrm{IC} 50\left(\mu \mathrm{g} \cdot \mathrm{mL}^{-1}\right)$ & References \\
\hline Anise & Commercial & 286.10 & (82) \\
\hline Balmmint & Commercial & 7.00 & $(82)$ \\
\hline Citrus limon & Leaves & 231.40 & (58) \\
\hline Citrus sinensis & Leaves & NSV* & (58) \\
\hline Clove & Commercial & 58.40 & $(82)$ \\
\hline Coriandrum sativum & Leaves & NSV & (58) \\
\hline Cymbopogon citratus & Leaves & 149.10 & (58) \\
\hline Cymbopogon citratus & Aerial parts & 38.00 & (76) \\
\hline Dwarf Pine & Commercial & 111.80 & $(82)$ \\
\hline Konuka & Commercial & 26.20 & $(82)$ \\
\hline Lavandula angustifolia & N/A & 110.00 & (83) \\
\hline Manuka & Commercial & 208.10 & $(82)$ \\
\hline Mentha pulegium & Aerial parts & 1.30 & (84) \\
\hline Ocimum basilicum & Leaves & 315.55 & (58) \\
\hline Origanum vulgare & Leaves & NSV & (58) \\
\hline Peppermint & Commercial & 227.50 & (82) \\
\hline Pine & Commercial & 123.20 & (82) \\
\hline Piper auritum & Leaves & 29.10 & (54) \\
\hline Pulicaria vulgaris & Aerial parts & 244.70 & (79) \\
\hline Rosemary & Commercial & 282.10 & (82) \\
\hline Rosmarinus officinalis & Aerial parts & 1.20 & (84) \\
\hline Rosmarinus officinalis & Leaves & NSV & (58) \\
\hline Rosmarinus officinalis & $\mathrm{N} / \mathrm{A}$ & 260.00 & (83) \\
\hline Satureja bakhtiarica & Leaves & 150.00 & (85) \\
\hline Spruce & Commercial & 29.90 & (82) \\
\hline Tea Tree & Commercial & 403.00 & $(82)$ \\
\hline Thyme & Commercial & 127.40 & $(82)$ \\
\hline Thymus capitellatus & Aerial parts & 62.00 & (80) \\
\hline Thymus hirtus & N/A & 0.43 & (74) \\
\hline Thymus vulgaris & Leaves & NSV & (58) \\
\hline Zingiber officinale & Leaves & 256.95 & (58) \\
\hline
\end{tabular}

*No specified value; IC50 > X.

leishmaniasis in the New World (6). Between the reported IC50s ( $\left.\mu \mathrm{g} . \mathrm{mL}^{-1}\right)$, EOs of Cinnamomum cassia (2.90) Zingiber zerumbet (3.30) and Ocimum gratissimum (4.80) were more effective than others (86).

Table 8 briefs the effect of 9 plant-derived EOs on $L$. panamensis promastigotes. Recently, it revealed that $L$. panamensis found in Central and South America, as well as it is the causative agent of the mucosal form (89). Origanum vulgare EO with IC50 of $42.23 \mu \mathrm{g} \cdot \mathrm{mL}^{-1}$ was better than others (58).

Results of LCA of many EOs on promastigotes of $L$. tropica are given in Table 9. In the Middle East and North Africa, L. tropica and L. major are two main causative agents of human cutaneous leishmaniasis (7). Results demonstrated that 2 EOs, including Myrtus communis
Table 7. Leishmanicidal activities of EOs against promastigotes of Leishmania mexicana

\begin{tabular}{lccc}
\hline Plant name & Part(s) of use & $\begin{array}{c}\text { IC50 } \\
\left(\mu \mathrm{g} \cdot \mathrm{mL}^{-1} \text { ) }\right.\end{array}$ & References \\
\hline Amomum aromaticum & Fruits & 9.20 & $(86)$ \\
Cinnamomum cassia & Stem barks & 2.90 & $(86)$ \\
Elsholtzia ciliata & Leaves & 8.40 & $(86)$ \\
Haplophyllum tuberculatum & Seed & 16.00 & $(87)$ \\
Haplophyllum tuberculatum & Leave & 16.60 & $(87)$ \\
Keetia leucantha & Leaves & 20.90 & $(88)$ \\
Ocimum gratissimum & Leaves & 4.80 & (86) \\
Piper auritum & Leaves & 63.30 & $(54)$ \\
Zingiber zerumbet & Rhizomes & 3.30 & $(86)$ \\
\hline
\end{tabular}

Table 8. Leishmanicidal activities of EOs against promastigotes of Leishmani panamensis

\begin{tabular}{lccc}
\hline Plant name & Part(s) of use & IC50 $\left(\mu \mathrm{g} \cdot \mathrm{mL}^{-1}\right)$ & References \\
\hline Citrus limon & Leaves & NSV* & $(58)$ \\
Citrus sinensis & Leaves & NSV & $(58)$ \\
Coriandrum sativum & Leaves & 427.95 & $(58)$ \\
Cymbopogon citratus & Leaves & 180.83 & $(58)$ \\
Ocimum basilicum & Leaves & 251.59 & $(58)$ \\
Origanum vulgare & Leaves & 42.23 & $(58)$ \\
Rosmarinus officinalis & Leaves & $\mathrm{NSV}$ & $(58)$ \\
Thymus vulgaris & Leaves & 402.23 & $(58)$ \\
Zingiber officinale & Leaves & 154.83 & $(58)$ \\
\hline
\end{tabular}

*No specified value; IC50 > X.

Table 9. Leishmanicidal activities of EOs against promastigotes of Leishmania tropica

\begin{tabular}{lccc}
\hline Plant name & Part(s) of use & IC50 $\left(\boldsymbol{\mu g} \cdot \mathrm{mL}^{-1}\right)$ & References \\
\hline Cymbopogon citratus & Aerial parts & 52.00 & $(76)$ \\
Myrtus communis & Leaves & 8.40 & $(90)$ \\
Nigella sativa & Seeds & 9.30 & $(78)$ \\
Thymus capitellatus & Aerial parts & 35.00 & $(80)$ \\
Zataria multiflora Boiss & Aerial parts & 89.30 & $(91)$ \\
\hline
\end{tabular}

and Nigella sativa with IC50 of 8.40 and $9.30 \mu \mathrm{g} \cdot \mathrm{mL}^{-1}$ respectively, were potent than others.

In Tables 1-9, 179 IC50s of EOs on promastigotes of 9 types of Leishmania were gathered. The documented IC50s ( $\mu \mathrm{g} . \mathrm{mL}^{-1}$ ) have been categorized as follow: IC50 <1: 6 EOs, IC50 1-10: 29 EOs, 10-100: 79 EOs, 100500: $40 \mathrm{EOs,} \mathrm{and} \mathrm{no} \mathrm{specified} \mathrm{value} \mathrm{(NSV):} 25 \mathrm{EOs}$ (i.e., IC50 $<\mathrm{X})$. LCA of 24 EOs has been examined against at least 2 species of Leishmania. However, just LCA of 2 EOs on targeted promastigotes was under $10 \mu \mathrm{g} \cdot \mathrm{mL}^{-1}$ simultaneously; Thymus hirtus EO with IC50s of 0.25 and 0.43 against $L$. infantum and L. major, respectively (74). 
Besides, EO of Nectandra gardneri was also showed good LCA on L. amazonensis (2.1 $\left.\mu \mathrm{g} \cdot \mathrm{mL}^{-1}\right)$ and L. infantum (2.7 $\left.\mu \mathrm{g} . \mathrm{mL}^{-1}\right)$ (36).

Interestingly, some EOs showed excellent LCA on one type of promastigotes, while its efficiency on an/ other species was not acceptable. For instance, EO of Ocimum gratissimum was demonstrated substantial IC50s against L. mexicana $\left(4.80 \mu \mathrm{g} \cdot \mathrm{mL}^{-1}\right)(86)$, L. chagasi $(75.00$ $\left.\mu \mathrm{g} \cdot \mathrm{mL}^{-1}\right)$ (64), and L. amazonensis (135 $\left.\mu \mathrm{g} \cdot \mathrm{mL}^{-1}\right)$ (38). Also, Nectandra megapotamica EO against L. amazonensis and L. infantum was indicated different IC50s $\left(\mu \mathrm{g} \cdot \mathrm{mL}^{-1}\right)$, including 6.66 (37) and 12.50 (36), respectively.

Furthermore, IC50 of Coriandrum sativum EO on $L$. amazonensis and L. chagasi was reported as $19.10 \mu \mathrm{g} \cdot \mathrm{mL}^{-1}$ (30) and $181.00 \mu \mathrm{g} \cdot \mathrm{mL}^{-1}(62)$, respectively, while this value for L. panamensis was achieved at $427.95 \mu \mathrm{g} \cdot \mathrm{mL}^{-1}(58)$. Besides, IC50s for Piper auritum EO against L. donovani, L. major, L. braziliensis, and L. mexicana were reported at $12.80,29.10,52.10$, and $63.30 \mu \mathrm{g} \cdot \mathrm{mL}^{-1}$, respectively (54). Based on the results, it can be said that the LCA of EOs against different species is selective.

\section{Conclusion}

The articles published over the last 20 years on the leishmanicidal activity of EOs have been systematically reviewed. IC50s of 179 EOs on promastigotes of 9 different species of Leishmania were also documented, separately. Interestingly, thirty-five of IC50 values were lower than $10 \mu \mathrm{g} \cdot \mathrm{mL}^{-1}$, thus could be introduced for further investigations such as preparation of nano/formulations, performing in-vivo studies, and clinical trials. However, given the selective properties of EOs, their combination can lead to good results. In other words, depending on the endemic leishmaniasis, EOs can be combined and formulated as multifunctional drugs. In addition, the categorized results in this research would be an excellent guide for other researchers to select proper EOs.

\section{Authors' contributions}

SNG contributed to the extraction of information from literature and providing of information on leishmaniasis. NS contributed in extraction of information from literature and providing of information on information about EOs. The idea of doing this research as well as writing the manuscript done by MO. All authors read and approved the final report.

\section{Conflict of interests}

There is no conflict of interest to declare.

\section{Ethical considerations}

Ethical issues have been observed by the authors.

\section{Funding/Support}

The authors appreciate Fasa University of Medical Sciences for financial support of this research, grant number of 97098.

\section{References}

1. Alvar J, Vélez ID, Bern C, Herrero M, Desjeux P, Cano J, et al. Leishmaniasis worldwide and global estimates of its incidence. PloS one. 2012;7(5):e35671.

2. Yaghoobi-Ershadi M, Hanafi-Bojd A, Akhavan A, ZahraiRamazani A, Mohebali M. Epidemiological study in a new focus of cutaneous leishmaniosis due to Leishmania major in Ardestan town, central Iran. Acta tropica. 2001;79(2):115-21.

3. Desjeux P. The increase in risk factors for leishmaniasis worldwide. Trans R Soc Trop Med Hyg. 2001;95(3):239-43.

4. WHO WHO. Report of a meeting of the WHO Expert Committee on the Control of Leishmaniases, Geneva, Switzerland, 22-26 March 2010. WHO Technical Report Series. 2010(949).

5. Dutra FL, Oliveira MM, Santos RS, Silva WS, Alviano DS, Vieira DP, et al. Effects of linalool and eugenol on the survival of Leishmania (L.) infantum chagasi within macrophages. Acta tropica. 2016;164:69-76.

6. Solano-Gallego L, Koutinas A, Miró G, Cardoso L, Pennisi M, Ferrer L, et al. Directions for the diagnosis, clinical staging, treatment and prevention of canine leishmaniosis. Vet Parasitol. 2009;165(1-2):1-18.

7. de Morais SM, Vila-Nova NS, Bevilaqua CML, Rondon FC, Lobo CH, Moura AdAAN, et al. Thymol and eugenol derivatives as potential antileishmanial agents. Bioorganic \& medicinal chemistry. 2014;22(21):6250-55.

8. Postigo JAR. Leishmaniasis in the world health organization eastern Mediterranean region. Int J Antimicrob Agents. 2010;36:S62-5.

9. Osanloo M, Amani A, Sereshti H, Shayeghi M, Sedaghat MM. Extraction and chemical composition essential oil of Kelussia odoratissima and comparison its larvicidal activity with Z-ligustilide (major constituent) against Anopheles stephensi. J Entomol Zool Stud. 2017;25:27.

10. Osanloo M, Amani A, Sereshti H, Abai MR, Esmaeili F, Sedaghat MM. Preparation and optimization nanoemulsion of Tarragon (Artemisia dracunculus) essential oil as effective herbal larvicide against Anopheles stephensi. Ind Crops Prod. 2017;109:214-19.

11. Osanloo M, Sedaghat MM, Esmaeili F, Amani A. Larvicidal Activity of Essential Oil of Syzygium aromaticum (Clove) in Comparison with Its Major Constituent, Eugenol, against Anopheles stephensi. J Arthropod Borne Dis. 2018;12(4):361-69.

12. Osanloo M, Sereshti H, Sedaghat MM, Amani A. Nanoemulsion of Dill essential oil as a green and potent larvicide against Anopheles stephensi. Environ Sci Pollut Res Int. 2018;25(7):6466-73.

13. Peixoto LR, Rosalen PL, Ferreira GLS, Freires IA, de Carvalho FG, Castellano LR, et al. Antifungal activity, mode of action and anti-biofilm effects of Laurus nobilis Linnaeus essential oil against Candida spp. Archives of oral biology. 2017;73:179-85.

14. Osanloo M, Sedaghat MM, Sanei-Dehkordi A, Amani A. Plant-derived essential oils; their larvicidal properties and potential application for control of Mosquito-Borne diseases. Galen. 2019;8:1532.

15. Luna EC, Luna IS, Scotti L, et al. Active essential oils and 
their components in use against neglected diseases and arboviruses. Oxid Med Cell Longev. 2019;2019:6587150. doi:10.1155/2019/6587150

16. Moraes Neto RN, Setubal RFB, Higino TMM, Brelaz-deCastro MCA, da Silva LCN, Alianca A. Asteraceae plants as sources of compounds against leishmaniasis and Chagas disease. Front Pharmacol. 2019;10:477. doi: 10.3389/ fphar.2019.00477.

17. Silveira FT, Lainson R, Corbett CE. Further observations on clinical, histopathological, and immunological features of borderline disseminated cutaneous leishmaniasis caused by Leishmania (Leishmania) amazonensis. Mem Inst Oswaldo Cruz. 2005;100(5):525-34. doi: 10.1590/s007402762005000500013.

18. Cardoso BM, de Mello TF, Lopes SN, Demarchi IG, Lera DS, Pedroso RB, et al. Antileishmanial activity of the essential oil from Tetradenia riparia obtained in different seasons. Mem Inst Oswaldo Cruz. 2015;110(8):1024-34. doi: 10.1590/0074-02760150290.

19. Demarchi IG, Thomazella MV, de Souza Terron M, Lopes L, Gazim ZC, Cortez DA, et al. Antileishmanial activity of essential oil and 6,7-dehydroroyleanone isolated from Tetradenia riparia. Exp Parasitol. 2015;157:128-37. doi: 10.1016/j.exppara.2015.06.014.

20. Terron-Monich MS, Demarchi IG, da Silva PRF, Ramos-Milare A, Gazim ZC, Silveira TGV, et al. 6,7-Dehydroroyleanone diterpene derived from Tetradenia riparia essential oil modulates IL-4/IL-12 release by macrophages that are infected with Leishmania amazonensis. Parasitol Res. 2019 Jan;118(1):369-376. doi: 10.1007/s00436-018-6166-2.

21. Santos AO, Santin AC, Yamaguchi MU, Cortez LE, UedaNakamura T, Dias-Filho BP, et al. Antileishmanial activity of an essential oil from the leaves and flowers of Achillea millefolium. Ann Trop Med Parasitol. 2010;104(6):475-83. doi: $10.1179 / 136485910 x 12786389891281$.

22. Garcia MCF, Soares DC, Santana RC, Saraiva EM, Siani AC, Ramos MFS, et al. The in vitro antileishmanial activity of essential oil from Aloysia gratissima and guaiol, its major sesquiterpene against Leishmania amazonensis. Parasitology. 2018;145(9):1219-27. doi: 10.1017/ S0031182017002335

23. Tamargo B, Monzote L, Pinon A, Machin L, Garcia M, Scull R, et al. In vitro and in vivo evaluation of essential oil from Artemisia absinthium L. formulated in nanocochleates against cutaneous leishmaniasis. Medicines (Basel). 2017;4(2):38. doi: 10.3390/medicines4020038.

24. Monzote L, Pinon A, Sculli R, Setzer WN. Chemistry and leishmanicidal activity of the essential oil from Artemisia absinthium from Cuba. Nat Prod Commun. 2014;9(12):1799-804.

25. Andrade MA, Azevedo CD, Motta FN, Santos ML, Silva CL, Santana JM, et al. Essential oils: in vitro activity against Leishmania amazonensis, cytotoxicity and chemical composition. BMC Complement Altern Med. 2016;16(1):444. doi: 10.1186/s12906-016-1401-9.

26. Monzote L, Nance MR, Garcia M, Scull R, Setzer WN. Comparative chemical, cytotoxicity and antileishmanial properties of essential oils from Chenopodium ambrosioides. Nat Prod Commun. 2011;6(2):281-6.

27. Monzote L, Montalvo AM, Scull R, Miranda M, Abreu J. Activity, toxicity and analysis of resistance of essential oil from Chenopodium ambrosioides after intraperitoneal, oral and intralesional administration in $\mathrm{BALB} / \mathrm{c}$ mice infected with Leishmania amazonensis: a preliminary study. Biomed Pharmacother. 2007;61(2-3):148-53. doi: 10.1016/j. biopha.2006.12.001.

28. Monzote L, Garcia M, Pastor J, Gil L, Scull R, Maes L, et al. Essential oil from Chenopodium ambrosioides and main components: activity against Leishmania, their mitochondria and other microorganisms. Exp Parasitol. 2014;136:20-6. doi: 10.1016/j.exppara.2013.10.007.

29. Teles AM, Rosa T, Mouchrek AN, Abreu-Silva AL, Calabrese KDS, Almeida-Souza F. Cinnamomum zeylanicum, Origanum vulgare, and Curcuma longa Essential Oils: Chemical Composition, Antimicrobial and Antileishmanial Activity. Evid Based Complement Alternat Med. 2019;2019:2421695. doi: 10.1155/2019/2421695.

30. Monzote L, Herrera I, Satyal P, Setzer WN. In-vitro evaluation of 52 commercially-available essential oils against Leishmania amazonensis. Nat Prod Res. 2019;24(7). doi: doi: 10.3390/molecules24071248.

31. Andrade PM, Melo DC, Alcoba AET, Ferreira Junior WG, Pagotti MC, Magalhaes LG, et al. Chemical composition and evaluation of antileishmanial and cytotoxic activities of the essential oil from leaves of Cryptocarya aschersoniana Mez. (Lauraceae Juss.). An Acad Bras Cienc. 2018;90(3):2671-78. doi: 10.1590/0001-3765201820170332.

32. Santin MR, dos Santos AO, Nakamura CV, Dias Filho BP, Ferreira IC, Ueda-Nakamura T. In vitro activity of the essential oil of Cymbopogon citratus and its major component (citral) on Leishmania amazonensis. Parasitol Res. 2009;105(6):1489-96. doi: 10.1007/s00436-009-1578-7.

33. Rodrigues KA, Amorim LV, de Oliveira JM, Dias CN, Moraes DF, Andrade EH, et al. Eugenia uniflora L. Essential oil as a potential anti-leishmania agent: effects on Leishmania amazonensis and possible mechanisms of action. Evid Based Complement Alternat Med. 2013;2013:279726. doi: $10.1155 / 2013 / 279726$.

34. de Medeiros M, da Silva AC, Cito AM, Borges AR, de Lima SG, Lopes JA, et al. In vitro antileishmanial activity and cytotoxicity of essential oil from Lippia sidoides Cham. Parasitol Int. 2011;60(3):237-41. doi: 10.1016/j. parint.2011.03.004.

35. Carvalho CE, Sobrinho-Junior EP, Brito LM, Nicolau LA, Carvalho TP, Moura AK, et al. Anti-Leishmania activity of essential oil of Myracrodruon urundeuva (Engl.) Fr. All.: Composition, cytotoxity and possible mechanisms of action. Exp Parasitol. 2017;175:59-67. doi: 10.1186/s13104017-2396-0.

36. Maia JGS, Setzer WN, Bosquiroli LSS, Dos Santos Ferreira AC, Farias KS, da Costa EC, et al. In Vitro antileishmania activity of sesquiterpene-rich essential oils from Nectandra species. Int J Mol Sci. 2017;55(1):2285-91. doi: 10.1080/13880209.2017.1407803.

37. Almeida KCR, Silva BB, Alves CCF, Vieira TM, Crotti AEM, Souza JM, et al. Biological properties and chemical composition of essential oil from Nectandra megapotamica (Spreng.) Mez. leaves (Lauraceae). Nat Prod Res. 2019:1-5. doi: $10.1080 / 14786419.2019 .1608539$.

38. Ueda-Nakamura T, Mendonca-Filho RR, Morgado-Diaz JA, Korehisa Maza P, Prado Dias Filho B, Aparicio Garcia Cortez D, et al. Antileishmanial activity of Eugenol-rich essential oil from Ocimum gratissimum. Parasitol Int. 
2006;55(2):99-105. doi: 10.1016/j.parint.2005.10.006.

39. Alcoba AET, Melo DC, de Andrade PM, Dias HJ, Pagotti MC, Magalhaes LG, et al. Chemical composition and in vitro antileishmanial and cytotoxic activities of the essential oils of Ocotea dispersa (Nees) Mez and Ocotea odorifera (Vell) Rohwer (Lauraceae). Nat Prod Res. 2018;32(23):2865-2868. doi: 10.1080/14786419.2017.1385007.

40. Gutierrez Y, Montes R, Scull R, Sanchez A, Cos P, Monzote $\mathrm{L}$, et al. Chemodiversity associated with cytotoxicity and antimicrobial activity of Piper aduncum var. ossanum. Chem Biodivers. 2016;13(12):1715-19. doi: doi: 10.1002/ cbdv.201600133

41. Bernuci KZ, Iwanaga CC, Fernandez-Andrade CM, Lorenzetti FB, Torres-Santos EC, Faioes VD, et al. Evaluation of chemical composition and antileishmanial and antituberculosis activities of essential oils of Piper species. Molecules. 2016;21(12):E1698. doi: 10.3390/ molecules21121698.

42. Marques AM, Barreto AL, Batista EM, Curvelo JA, Velozo LS, Moreira Dde L, et al. Chemistry and biological activity of essential oils from Piper claussenianum (Piperaceae). Nat Prod Commun. 2010;5(11):1837-40.

43. Esperandim VR, da Silva Ferreira D, Sousa Rezende KC, Magalhaes LG, Medeiros Souza J, Pauletti PM, et al. In vitro antiparasitic activity and chemical composition of the essential oil obtained from the fruits of Piper cubeba. Planta Med. 2013;79(17):1653-5. doi: 10.1055/s-0033-1351022.

44. Moura do Carmo DF, Amaral AC, Machado GM, Leon LL, Silva JR. Chemical and biological analyses of the essential oils and main constituents of Piper species. Molecules. 2012;17(2):1819-29. doi: 10.3390/molecules17021819.

45. Garcia M, Scull R, Satyal P, Setzer WN, Monzote L. Chemical characterization, antileishmanial activity, and cytotoxicity effects of the essential oil from leaves of Pluchea carolinensis (Jacq.) G. Don. (Asteraceae). Phytother Res. 2017;31(9):1419-26. doi: 10.1002/ptr.5869.

46. Estevam EBB, Deus IPB, Silva VPD, Silva E, Alves CCF, Alves JM, et al. In vitro antiparasitic activity and chemical composition of the essential oil from Protium ovatum leaves (Burceraceae). An Acad Bras Cienc. 2017;89(4):3005-3013. doi: 10.1590/0001-3765201720170310.

47. Dias CN, Rodrigues KA, Carvalho FA, Carneiro SM, Maia JG, Andrade EH, et al. Molluscicidal and leishmanicidal activity of the leaf essential oil of Syzygium cumini (L.) SKEELS from Brazil. Chem Biodivers. 2013;10(6):1133-41. doi: $10.1002 / \mathrm{cbdv} .201200292$.

48. Rodrigues KA, Amorim LV, Dias CN, Moraes DF, Carneiro SM, Carvalho FA. Syzygium cumini (L.) Skeels essential oil and its major constituent alpha-pinene exhibit antiLeishmania activity through immunomodulation in vitro. J Ethnopharmacol. 2015;160:32-40. doi: 10.1016/j. jep.2014.11.024.

49. Hajaji S, Sifaoui I, Lopez-Arencibia A, Reyes-Batlle M, Jimenez IA, Bazzocchi IL, et al. Leishmanicidal activity of alpha-bisabolol from Tunisian chamomile essential oil. Parasitol Res. 2018;117(9):2855-67. doi: 10.1007/s00436018-5975-7.

50. Colares AV, Almeida-Souza F, Taniwaki NN, Souza Cda S, da Costa JG, Calabrese Kda S, et al. In Vitro antileishmanial activity of essential oil of Vanillosmopsis arborea (Asteraceae) Baker. Evid Based Complement Alternat Med. 2013;2013:727042. doi: 10.1155/2013/727042.
51. Kaszak I, Planellas M, Dworecka-Kaszak B. Canine leishmaniosis-an emerging disease. Ann Parasitol. 2015;61(2):69-76.

52. Barros LM, Duarte AE, Morais-Braga MF, Waczuk EP, Vega C, Leite NF, et al. Chemical characterization and trypanocidal, leishmanicidal and cytotoxicity potential of Lantana camara L. (Verbenaceae) Essential Oil. Molecules. 2016;21(2):209. doi: 10.3390/molecules21020209.

53. Ceole LF, Cardoso MDG, Soares MJ. Nerolidol, the main constituent of Piper aduncum essential oil, has anti-Leishmania braziliensis activity. Parasitology. 2017;144(9):1179-90. doi: 10.1017/S0031182017000452.

54. Monzote L, Garcia M, Montalvo AM, Scull R, Miranda M. Chemistry, cytotoxicity and antileishmanial activity of the essential oil from Piper auritum. Mem Inst Oswaldo Cruz. 2010;105(2):168-73. doi: 10.1590/s007402762010000200010 .

55. WHO. Fact sheets of leishmaniasis. Available from: https:// www.who.int/news-room/fact-sheets/detail/leishmaniasis. Accessed September 10, 2019.

56. WHO. Leishmaniasis cutaneous. Available from: https:// www.who.int/leishmaniasis/cutaneous_leishmaniasis/en. Accessed September 10, 2019.

57. Pereira PS, Maia AJ, Duarte AE, Oliveira-Tintino CDM, Tintino SR, Barros LM, et al. Cytotoxic and antikinetoplastid potential of the essential oil of Alpinia speciosa K. Schum. Food Chem Toxicol. 2018 Sep;119:387-391. doi: 10.1016/j.fct.2018.01.024.

58. Sanchez-Suarez J, Riveros I, Delgado G. Evaluation of the leishmanicidal and cytotoxic potential of essential oils derived from ten Colombian plants. Iran J Parasitol. 2013;8(1):129-36.

59. Dos Santos Sales V, Monteiro AB, Delmondes GA, do Nascimento EP, Sobreira Dantas Nobrega de Figueiredo FR, de Souza Rodrigues CK, et al. Antiparasitic Activity and Essential Oil Chemical Analysis of the Piper tuberculatum Jacq Fruit. Iran J Pharm Res. 2018;17(1):268-75.

60. Mauricio I, Stothard J, Miles M. The strange case of Leishmania chagasi. Parasitology today. 2000;16(5):188-89.

61. Razmjou S, Hejazy H, Motazedian MH, Baghaei M, Emamy M, Kalantary M. A new focus of zoonotic cutaneous leishmaniasis in Shiraz, Iran. Trans R Soc Trop Med Hyg. 2009;103(7):727-30.

62. Rondon FC, Bevilaqua CM, Accioly MP, de Morais SM, de Andrade-Junior HF, de Carvalho CA, et al. In vitro efficacy of Coriandrum sativum, Lippia sidoides and Copaifera reticulata against Leishmania chagasi. Rev Bras Parasitol Vet. 2012;21(3):185-91.

63. Rodrigues IA, Azevedo MM, Chaves FC, Bizzo HR, CorteReal S, Alviano DS, et al. In vitro cytocidal effects of the essential oil from Croton cajucara (red sacaca) and its major constituent 7- hydroxycalamenene against Leishmania chagasi. BMC Complement Altern Med. 2013;13:249. doi: 10.1186/1472-6882-13-249.

64. Oliveira VC, Moura DM, Lopes JA, de Andrade PP, da Silva NH, Figueiredo RC. Effects of essential oils from Cymbopogon citratus (DC) Stapf., Lippia sidoides Cham., and Ocimum gratissimum L. on growth and ultrastructure of Leishmania chagasi promastigotes. Parasitol Res. 2009;104(5):1053-9. doi: 10.1007/s00436-008-1288-6.

65. Escobar P, Milena Leal S, Herrera LV, Martinez JR, Stashenko E. Chemical composition and antiprotozoal activities 
of Colombian Lippia spp essential oils and their major components. Mem Inst Oswaldo Cruz. 2010;105(2):184-90. doi: $10.1590 / \mathrm{s} 0074-02762010000200013$.

66. de Melo JO, Bitencourt TA, Fachin AL, Cruz EM, de Jesus HC, Alves PB, et al. Antidermatophytic and antileishmanial activities of essential oils from Lippia gracilis Schauer genotypes. Acta Trop. 2013;128(1):110-5. doi: 10.1016/j. actatropica.2013.06.024.

67. Rhajaoui M, Nasereddin A, Fellah H, Azmi K, Amarir F, Al-Jawabreh A, et al. New clinicoepidemiologic profile of cutaneous leishmaniasis, Morocco. Emerg Infect Dis. 2007;13(9):1358.

68. Islamuddin $M$, Chouhan G, Tyagi M, Abdin MZ, Sahal D, Afrin F. Leishmanicidal activities of Artemisia annua leaf essential oil against Visceral Leishmaniasis. Front Microbiol. 2014;5:626. doi: 10.3389/fmicb.2014.00626.

69. Islamuddin M, Sahal D, Afrin F. Apoptosis-like death in Leishmania donovani promastigotes induced by eugenolrich oil of Syzygium aromaticum. J Med Microbiol. 2014;63(Pt 1):74-85. doi: 10.1099/jmm.0.064709-0.

70. Parreira NA, Magalhaes LG, Morais DR, Caixeta SC, de Sousa JP, Bastos JK, et al. Antiprotozoal, schistosomicidal, and antimicrobial activities of the essential oil from the leaves of Baccharis dracunculifolia. Chem Biodivers. 2010;7(4):993-1001. doi: 10.1002/cbdv.200900292.

71. Zheljazkov VD, Cantrell CL, Astatkie T, Hristov A. Yield, content, and composition of peppermint and spearmints as a function of harvesting time and drying. J Agric Food Chem. 2010;58(21):11400-7. doi: 10.1021/jf1022077.

72. Zheljazkov VD, Cantrell CL, Tekwani B, Khan SI. Content, composition, and bioactivity of the essential oils of three basil genotypes as a function of harvesting. J Agric Food Chem. 2008;56(2):380-5. doi: 10.1021/jf0725629.

73. WHO. Thirteenth Programme Report, UNDP/World Bank 1997.

74. Ahmed SB, Sghaier RM, Guesmi F, Kaabi B, Mejri M, Attia $\mathrm{H}$, et al. Evaluation of antileishmanial, cytotoxic and antioxidant activities of essential oils extracted from plants issued from the leishmaniasis-endemic region of Sned (Tunisia). Nat Prod Res. 2011;25(12):1195-201. doi: 10.1080/14786419.2010.534097.

75. Aloui Z, Messaoud C, Haoues M, Neffati N, Bassoumi Jamoussi I, Essafi-Benkhadir K, et al. Asteraceae Artemisia campestris and Artemisia herba-alba Essential oils trigger apoptosis and cell cycle arrest in Leishmania infantum Promastigotes. Evid Based Complement Alternat Med. 2016;2016:9147096. doi: 10.1155/2016/9147096.

76. Machado M, Pires P, Dinis AM, Santos-Rosa M, Alves V, Salgueiro L, et al. Monoterpenic aldehydes as potential antiLeishmania agents: activity of Cymbopogon citratus and citral on L. infantum, L. tropica and L. major. Exp Parasitol. 2012;130(3):223-31. doi: 10.1016/j.exppara.2011.12.012.

77. Siqueira CA, Serain AF, Pascoal AC, Andreazza NL, de Lourenco CC, Ruiz AL, et al. Bioactivity and chemical composition of the essential oil from the leaves of Guatteria australis A.St.-Hil. Nat Prod Res. 2015;29(20):1966-9. doi: 10.1080/14786419.2015.1015017.

78. Mahmoudvand H, Tavakoli R, Sharififar F, Minaie K, Ezatpour B, Jahanbakhsh S, et al. Leishmanicidal and cytotoxic activities of Nigella sativa and its active principle, thymoquinone. Pharm Biol. 2015;53(7):1052-7. doi: $10.3109 / 13880209.2014 .957784$.
79. Sharifi-Rad M, Salehi B, Sharifi-Rad J, Setzer WN, Iriti M. Pulicaria vulgaris Gaertn. essential oil: an alternative or complementary treatment for Leishmaniasis. Cell Mol Biol (Noisy-le-grand). 2018;64(8):18-21.

80. Machado M, Dinis AM, Santos-Rosa M, Alves V, Salgueiro L, Cavaleiro C, et al. Activity of Thymus capitellatus volatile extract, 1,8-cineole and borneol against Leishmania species. Vet Parasitol. 2014;200(1-2):39-49. doi: 10.1016/j. vetpar.2013.11.016.

81. Moreira RRD. Composition and leishmanicidal activity of the essential oil of Vernonia polyanthes Less (Asteraceae). Chem Biol Drug Des. 2017;31(24):2905-8. doi: 10.1080/14786419.2017.1299723.

82. Mikus J, Harkenthal M, Steverding D, Reichling J. In vitro effect of essential oils and isolated mono- and sesquiterpenes on Leishmania major and Trypanosoma brucei. Planta Med. 2000;66(4):366-8. doi: 10.1055/s-2000-8548.

83. Shokri A, Saeedi M, Fakhar M, Morteza-Semnani K, Keighobadi M, Hosseini Teshnizi S, et al. Antileishmanial activity of Lavandula angustifolia and Rosmarinus officinalis essential oils and nano-emulsions on Leishmania major (MRHO/IR/75/ER). Iran J Parasitol. 2017;12(4):622-31. doi: $10.1017 / \mathrm{s} 0031182017002335$.

84. Bouyahya A, Et-Touys A, Bakri Y, Talbaui A, Fellah $\mathrm{H}$, Abrini J, et al. Chemical composition of Mentha pulegium and Rosmarinus officinalis essential oils and their antileishmanial, antibacterial and antioxidant activities. Microb Pathog. 2017;111:41-9. doi: 10.1016/j. micpath.2017.08.015.

85. Mohammadpour G, Marzony ET, Farahmand M. Evaluation of the anti-Leishmania major activity of Satureja bakhtiarica essential oil in vitro. Nat Prod Commun. 2012;7(1):133-6.

86. Le TB, Beaufay C, Nghiem DT, Mingeot-Leclercq MP, Quetin-Leclercq J. In vitro anti-leishmanial activity of essential oils extracted from Vietnamese plants. Molecules. 2017;22(7):1071. doi: 10.3390/molecules22071071.

87. Hamdi A, Bero J, Beaufay C, Flamini G, Marzouk Z, Vander Heyden $\mathrm{Y}$, et al. In vitro antileishmanial and cytotoxicity activities of essential oils from Haplophyllum tuberculatum A. Juss leaves, stems and aerial parts. BMC Complement Altern Med. 2018;18(1):60. doi: 10.1186/s12906-018-21286.

88. Bero J, Beaufay C, Hannaert V, Herent MF, Michels PA, Quetin-Leclercq J. Antitrypanosomal compounds from the essential oil and extracts of Keetia leucantha leaves with inhibitor activity on Trypanosoma brucei glyceraldehyde3-phosphate dehydrogenase. Phytomedicine. 2013;20(34):270-4. doi: 10.1016/j.phymed.2012.10.010.

89. Showler AJ, Boggild AK. Cutaneous leishmaniasis in travellers: a focus on epidemiology and treatment in 2015. Curr Infect Dis Rep. 2015;17(37):489. doi: 10.1007/s11908015-0489-2.

90. Mahmoudvand H, Ezzatkhah F, Sharififar F, Sharifi I, Dezaki ES. Antileishmanial and cytotoxic effects of essential oil and methanolic extract of Myrtus communis L. Korean J Parasitol. 2015;53(1):21-7. doi: 10.3347/kjp.2015.53.1.21.

91. Saedi Dezaki E, Mahmoudvand H, Sharififar F, Fallahi S, Monzote L, Ezatkhah F. Chemical composition along with anti-leishmanial and cytotoxic activity of Zataria multiflora. Pharm Biol. 2016;54(5):752-8. doi: 10.3109/13880209.2015.1079223. 